\title{
The Pill and the blackboard
}

\author{
Martha Campbell, Malcolm Potts
}

Few people would deny that improvements in education, especially for women, are probably the single most powerful element driving socioeconomic development around the world. But how do family planning and education relate: is education a prerequisite for a fall in family size, or can access to family planning feed back into improved educational opportunities? How are the Pill and the blackboard related?

In many parts of the world - and across much of recent history - well-educated women have had fewer children than illiterate women. Indeed, the classical model of the demographic transition posits that low fertility is driven by exogenous socioeconomic factors, including education. Led by India and China, the 1974 United Nations population conference in Bucharest adopted the theme, using the words of India's commissioner of family planning: "Development is the best contraceptive". ${ }^{1}$ Countries that appear to fit this pattern include Afghanistan, which has low female literacy (about 10\%) and also low contraceptive use (about 5\%), and the Philippines, where contraception is framed as immoral and can be difficult to obtain, and educated women have much higher use of contraception than women who have had no schooling.

But correlations are not necessarily causal, and there are also countries that do not fit this pattern. The anonomalies are striking and cannot be ignored. In Bangladesh, only about one-third of adult women are literate, but contraceptive use is high (almost $60 \%$ use a method), and in Guyana virtually all women are literate but only one-third of them use contraception. In Thailand, where contraception is easy to obtain, unlike the Philippines, there is little difference in the percentage of women using contraception between those who are educated and those with no formal education. ${ }^{2-4}$ The rapid decline in fertility in Iran from 5.5 to 2 children after all methods of contraception were introduced in 1987 cannot be accounted for by a change in education or other socioeconomic factors. Nor can the astonishingly low fertility in Addis Ababa, Ethiopia, which reached 1.9 in 2002 with a desired family size of 1.6 .5 Indeed, the only factor that is consistent with all fertility decline around the world is the absence of barriers standing between women and the fertility regulation methods they need to have control over whether and when to bear a child.

How do we explain, then, the frequent correlations around the world between education and family size? In our view, the plausible explanation is that education has an indirect, rather than a direct, relationship with low fertility, because the well-educated women - and more wealthy women as well - are better able to surmount the barriers that stand between them and the means to manage their reproductive lives.

\section{J Fam Plann Reprod Health Care 2006; 32(3): 147-148}

School of Public Health, University of California, Berkeley, CA, USA

Martha Campbell, PhD, Lecturer

Malcolm Potts, PhD, FRCOG, Bixby Professor

Correspondence to: Dr Martha Campbell, School of Public Health, 506 Warren Hall, University of California, Berkeley, CA 94720-7360, USA. E-mail: mcbell@berkeley.edu
Human couples have sex hundreds or often thousands of times more frequently than is needed to conceive their desired number of children. It follows that the voluntary control of family size turns not so much on a positive decision to have a child, but on the ability to turn off unwanted fertility. Those working in family planning are only too aware of the many barriers that often stand between a woman and the contraceptive technologies and safe abortion she needs to manage her family size. Social pressures, perverse legislation, patriarchal theologies and restrictive medical practices often build almost insurmountable barriers to the use of fertility regulation. The asymmetry in the way society treats Viagra ${ }^{\circledR}$ and the Pill suggests that the striving of men to control women's reproduction is deeply rooted in men's nature. ${ }^{6}$

In Africa, clinics often run out of contraceptives and, when they have them, women are often turned away because they are not menstruating on that day. Uneducated and poor women have little negotiation power, but it may be even more important that they are stranded without correct information, lacking the analytical tools to tell the difference between misinformation and the more probable truth. Surveys have shown in many countries that, despite many decades of well-documented, safe use, many women still perceive the Pill as more dangerous than childbirth or likely to lead to infertility later. ${ }^{7}$ Under these circumstances, the perceived cost of using contraception can easily be seen by women as higher than the cost of having another pregnancy. The list of barriers between women and the means they need to decide when to have a child is so long that it is a wonder that so many poor women in developing countries manage to control their family size at all. ${ }^{8}$

Induced abortion is an essential variable determining any country's average family size. A global review of abortion statistics by the Guttmacher Institute in New York suggests that on average every woman will have one induced abortion over her lifetime. The rich can always buy a safe abortion in any country, while the poor are more often left to complete an unintended pregnancy. Laws restricting abortion are an obvious barrier to fertility regulation. No country has replacement level fertility or below without widespread access to safe abortion. This may be where abortion is legal, as in England, Wales and Scotland, or it may be where it is not legal but accessible, as in the Republic of Ireland, from where it is possible to terminate an unwanted pregnancy in England. In Italy and Spain in the 1960s, when contraception was difficult to obtain and abortion was illegal, the total fertility rates (TFRs) were 2.5 and 2.9 , respectively, but since fertility regulation has became realistically accessible, the TFR rate of both countries has plummeted to 1.3. The level of education hardly changed, but access to modern contraception and safe abortion for all socioeconomic groups had a revolutionary impact.

The evidence does indeed strongly suggest that the arrow of causation is not so much from education to smaller families but from smaller families to the likelihood of better education. An important study in the 1980 s conducted by John Knodel $^{9}$ showed that in Thailand, as the TFR fell from six to two, those parents with two children were more likely to see their children enter school and remain in school, compared with families with four or more children, even when all other 
socioeconomic variables were taken into account. Even without expensive social science surveys, poor and illiterate people know the power of education, and they understand that having fewer children will improve their children's educational opportunities. Governments in countries with high average birth rates - with the exception of a few oil-rich states - are generally unable to provide new schools and teachers at the rate of growth of each new cohort of young people.

We know from our own observations and from countless studies that education is an immensely powerful driver of social change and improvement. At the level of basic health, an educated woman looks after her own health and that of her children more successfully than an uneducated woman. Education - especially the education of women - opens the door to greater wealth and hopefully greater fulfilment. The fact that the mother's access to contraception can improve the educational opportunities of her children, as well as her health and that of her infants, is an insight we should always value. At a conference in India in 1993, faced with compelling evidence from 30 years of international assistance to family planning, India's former commissioner of family planning reversed his 1974 aphorism, by proclaiming: "Contraception is the best development." 10
Statements on funding and competing interests

Funding. None identified.

Competing interests. None identified.

References

1 Finkle JL, Crane BB. The politics of Bucharest: population, development, and the New International Economic Order. Popul Dev Rev 1975; 1: 87-114.

2 Lee K, Lush L, Walt G, Cleland J. Population Policies and Programmes: Determinants and Consequences in Eight Developing Countries. London, UK: London School of Hygiene and Tropical Medicine, 1995.

3 Potts M. Sex and the birth rate: human biology, demographic change, and access to fertility regulation methods. Popul Dev Rev 1997; 23: $1-40$.

4 Cleland J, Wilson C. Demand theories of the fertility transition: an iconoclastic view. Popul Stud 1987; 41: 5-30.

5 Sibanda A, Woubalem Z, Hogan D, Lindstrom D. The proximate determinants of the decline to below-replacement fertility in Addis Ababa, Ethiopia. Stud Fam Plann 2003; 34: 1-7.

6 Potts M. Why can't a man be more like a woman? Sex, power, and politics. Obstet Gynecol 2005; 106: 1065-1070.

7 Grubb GS. Women's perception of the safety of the pill: a survey in eight developing countries. J Biosoc Sci 1987; 19: 313-321.

8 Campbell M, Salin-Hodoglugil N, Potts M. Barriers to fertility regulation: a review of the literature. Stud Fam Plann 2006; 37: 87-98.

9 Knodel J, Wongsith M. Family size and children's education in Thailand: evidence from a national sample. Demography 1991; 28: 119-131.

10 Potts M. Contraception is the best development. Lancet 1992; 340 1201

\section{Visit the Faculty Website at: www.ffprhc.org.uk}

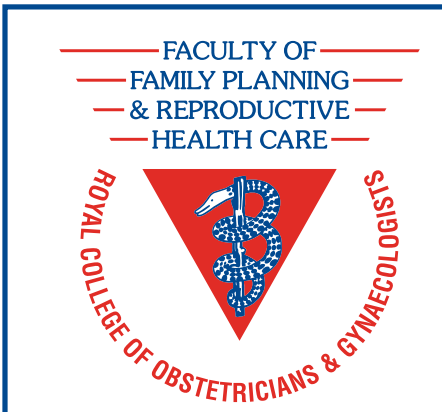

\section{ASSOCIATE MEMBERSHIP OF THE FFPRHC IS NOW OPEN TO NURSES ANNUAL SUBSCRIPTION $£ 40$}

\section{Associate membership of the Faculty of Family Planning and Reproductive Heath Care is open to all nurses with a special interest in contraception and reproductive health.}

Article 3.9: Persons not medically qualified but who have made an important contribution to and are working in the sphere of the Faculty and medical practitioners who are permanently retired from clinical practice, due to age or ill health, may on application to the Council be accepted for Associate Membership.

This subscription entitles Associate Members to copies of the Journal of Family Planning and Reproductive Health Care and access to the members' enquiry service.

The Journal of Family Planning and Reproductive Health Care is published quarterly, on behalf of the Faculty of Family Planning and Reproductive Health Care, by PMH Publications.

Membership now includes FREE access to the electronic journal, managed by Ingenta.

Associate Membership Application Forms are available on the website: www.ffprhc.org.uk or by telephoning: $+44(0) 2077245647 / 5669 / 5524$

FACULTY OF FAMILY PLANNING AND REPRODUCTIVE HEALTH CARE of the Royal College of Obstetricians and Gynaecologists 27 Sussex Place, Regent's Park, London NW1 4RG, UK 